\title{
Phyllotaxis and handedness in date palm (Phœnix dactylifera L.)
}

\author{
Mohammed Aziz Elhoumaizij ${ }^{a \star}$, René Lecoustre ${ }^{b}$, Abedllah Oihabic $^{\mathrm{c}}$
}

a University Mohammed 1st, Faculty of Sciences, Department of Biology, BP 724 Oujda 60 000, Morocco

houmaizi@sciences.univ-

oujda.ac.ma

b Cirad-amis, UMRA-AMAP,

Avenue la Lironde,

PS2 / TA 40,

34398 Montpellier Cedex 5,

France

c University Cadi-Ayyad,

Faculty of Sciences Semlalia, Department of Biology,

BP 2390, Marrakech 40000 ,

Morocco
* Correspondence and reprints

Received 20 July 2001 Accepted 2 May 2002

Fruits, 2002, vol. 57, p. 297-303 (C) 2002 Cirad/EDP Sciences All rights reserved DOI: 10.1051/fruits:2002026

RESUMEN EsPañol, p. 303

\section{Phyllotaxis and handedness in the date palm (Phœnix dactylifera L.).}

Abstract - Introduction. The present study had as objectives to measure the palm leaf divergence angle in the field, to determine the frequency of trees and offshoots showing clockwise and counterclockwise phyllotaxis, to establish the relationship between phyllotaxis of the mother tree and that of its offshoots, and, finally, to determine the effect of the divergence angle value on production. Materials and methods. The vegetal material was composed of four Moroccan cultivars of Phoenix dactylifera L. Observations were conducted in the south of Morocco on 20 trees per cultivar and four offshoots per tree. The divergence angle was measured on adult trees whereas phyllotaxic direction (clockwise or counterclockwise) was noted for both offshoots and adult trees. Results and discussion. This study showed that the phyllotaxic direction of the offshoots presents a clockwise or counterclockwise phyllotaxis independently of the mother plant. The divergence angle varied depending on the cultivar. This character is an interesting criterion, both for the selection of the best adapted cultivars for the marginal date palm growing regions, and for an optimal production.

\section{Morocco / Pboenix dactylifera / phyllotaxy}

\section{Sens dominant de la phyllotaxie chez le palmier dattier (Phœnix dactylifera L.).}

Résumé - Introduction. L'étude présentée a eu pour objectif de mesurer en champ l'angle de divergence de l'insertion des palmes sur le tronc de palmiers dattiers, de déterminer la fréquence des phyllotaxies droites ou gauches de plants adultes et de leurs rejets, d'évaluer le rapport entre la phyllotaxie de l'arbre mère et celle de ses rejets, et, finalement, de déterminer l'effet de l'angle de divergence des palmes sur la production du palmier. Matériel et méthodes. Le matériel végétal a été composé de quatre cultivars marocains de Phonix dactylifera $\mathrm{L}$. Les observations ont été conduites dans le sud du Maroc sur 20 palmiers adultes par cultivar et quatre rejets par palmier adulte. L'angle de divergence a été mesuré sur des palmiers adultes tandis que le sens phyllotaxique (gauche ou droite) a été observé à la fois sur les arbres adultes et sur leurs rejets. Résultats et discussion. Notre étude a montré que le sens phyllotaxique des rejets est indépendant de celui de la plante mère. L'angle de divergence a varié selon le cultivar. Ce caractère est un critère intéressant pour choisir des cultivars adaptés à une production marginale du palmier dattier ou à des conditions de production optimale.

\section{Maroc / Phoenix dactylifera / phyllotaxie}




\section{Introduction}

Throughout the world, production systems of the date palm (Phonix dactylifera L.) in oases are spread over 800000 ha, which represents more than 100 million trees [1]. As part of a staple diet, the date palm is also suitable for multi-layer cropping practices.

The date palm is a dioecious monocotyledon; its vegetative propagation through shoot cuttings is widely practiced. The leaves of palm trees are arranged in helices and, depending on the species, present as a single conspicuous parastichy (Areca catechu), as two conspicuous parastichies (Chamaedorea costaricana) or as several conspicuous parastichies (Cocos nucifera, Elaeis guineensis, Phonix dactylifera L.) [2]. The regular, almost mathematical geometric arrangement of the new leaves is governed by a numerical regularity consistent with Fibonacci sequences [3-5].

Several papers have dealt with phyllotaxis in Arecaceae, particularly in oil palm and coconut tree [2, 6-10]. Only one phyllotaxis study has been done on date palm tree [11]. All these studies, with the exception of the work conducted by Hirsch [12], focused on the frequency of cultivars showing clockwise and counterclockwise phyllotaxis, but none has measured the divergence angle.

The present study had as objectives to measure the divergence angle in the field, to determine the frequency of trees and offshoots showing clockwise and counterclockwise phyllotaxis, to establish the relationship between phyllotaxis of the mother tree and that of its offshoots, and, finally, to determine the effect of the divergence angle value on production.

\section{Materials and methods}

The vegetal material was composed of four Moroccan cultivars: Bousthammie noire, Sair layalet, Bousthammie blanche and Jihel. All cultivars were cultivated under similar ecological conditions and were equally maintained at the Experimental
Domain of Nbech in Zagora (Inra of Morocco) in the south of Morocco. Observations were conducted on 20 trees per cultivar and four offshoots per tree.

Phyllotaxic arrangement gives rise to conspicuous parastichies along the stem marked by petiolar bases and palms. Visible parastichy sequence 8 in leaf 1 gave rise to contacts with leaves $9,17,25, \ldots, 65, \ldots$ Visible parastichy sequence 5 in leaf 3 gave rise to contacts with leaves $8,13, \ldots, 58, \ldots$ (figure 1).

Locating apparent spirals (parastichies): a leaf (base) of rank $\mathrm{X}$ is surmounted by three neighboring leaves which are of rank $\mathrm{X}-8, \mathrm{X}-13$ and $\mathrm{X}-5$. There is also a very close leaf whose rank is $\mathrm{X}-3$. Leaves ranked $\mathrm{X}-8$ and $\mathrm{X}-3$ are located on the same side of a vertical generator passing through leaves ranked $\mathrm{X}$. Leaves ranked $\mathrm{X}-13$ and $\mathrm{X}-5$ are situated on the other side. The location of each leaf was therefore noted and numbered (figure 1).

An examination of the visible parastichies in sequence 8 showed that the parastichies turned in the opposite direction to the emerging leaves. The phyllotaxic parastichies may curve right or left (clockwise or counterclockwise) depending on the individual. The angle formed by two leaves $\mathrm{X}$ to $\mathrm{Y}$ units from the parastichy ' 8 ' was used to calculate the divergence angle or the angle formed by two leaves emerging successively. Projection onto the soil of distant leaves permits the calculation of the alpha angle through trigonometric resolution [13] (figure 2):

$\alpha=2 \arcsin \left[\left(\mathrm{d}_{2}-\mathrm{d}_{1}\right) / 2\right]$,

$\alpha$ : alpha angle; $\mathrm{d}_{1}, \mathrm{~d}_{2}$ : distance between the projection onto the soil of the leaves $\mathrm{X}$ and $\mathrm{Y}$,

$\phi=[1 /(\mathrm{X}-\mathrm{Y})] \times \alpha+135$,

$\phi$ : divergence angle, $\mathrm{X}$ : numeral of higher leaf, Y: numeral of lower leaf.

The divergence angle was measured on adult trees whereas phyllotaxic direction (clockwise or counterclockwise) was noted for both offshoots and adult trees. 

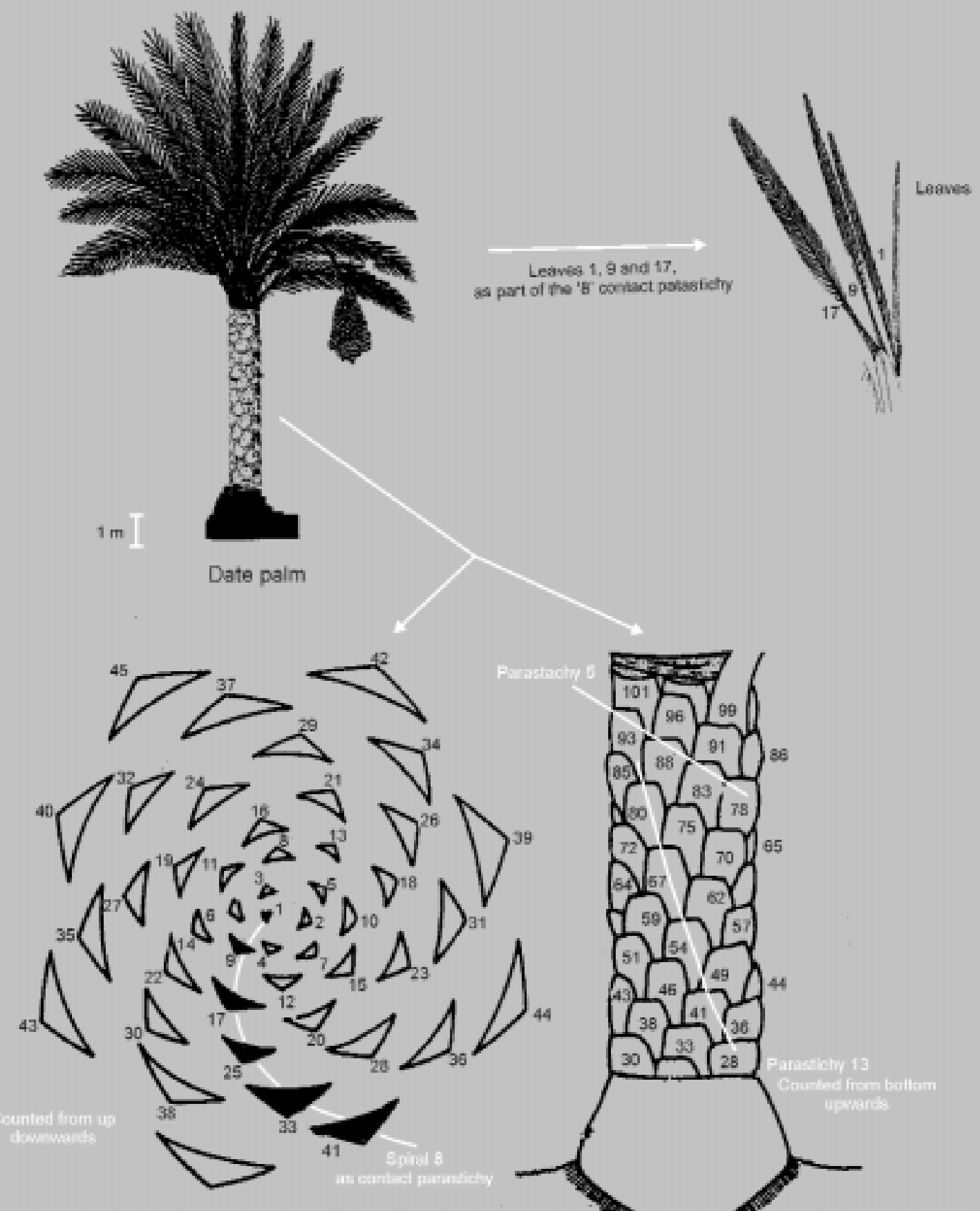

Diagram of the phyllotaxy of date paim

Stem

Figure 1.

Numbering of leaves for Phoenix dactylifera L. according to parastichies with numeral 5, 8 and 13 (as typical for Fibonacci systems). 


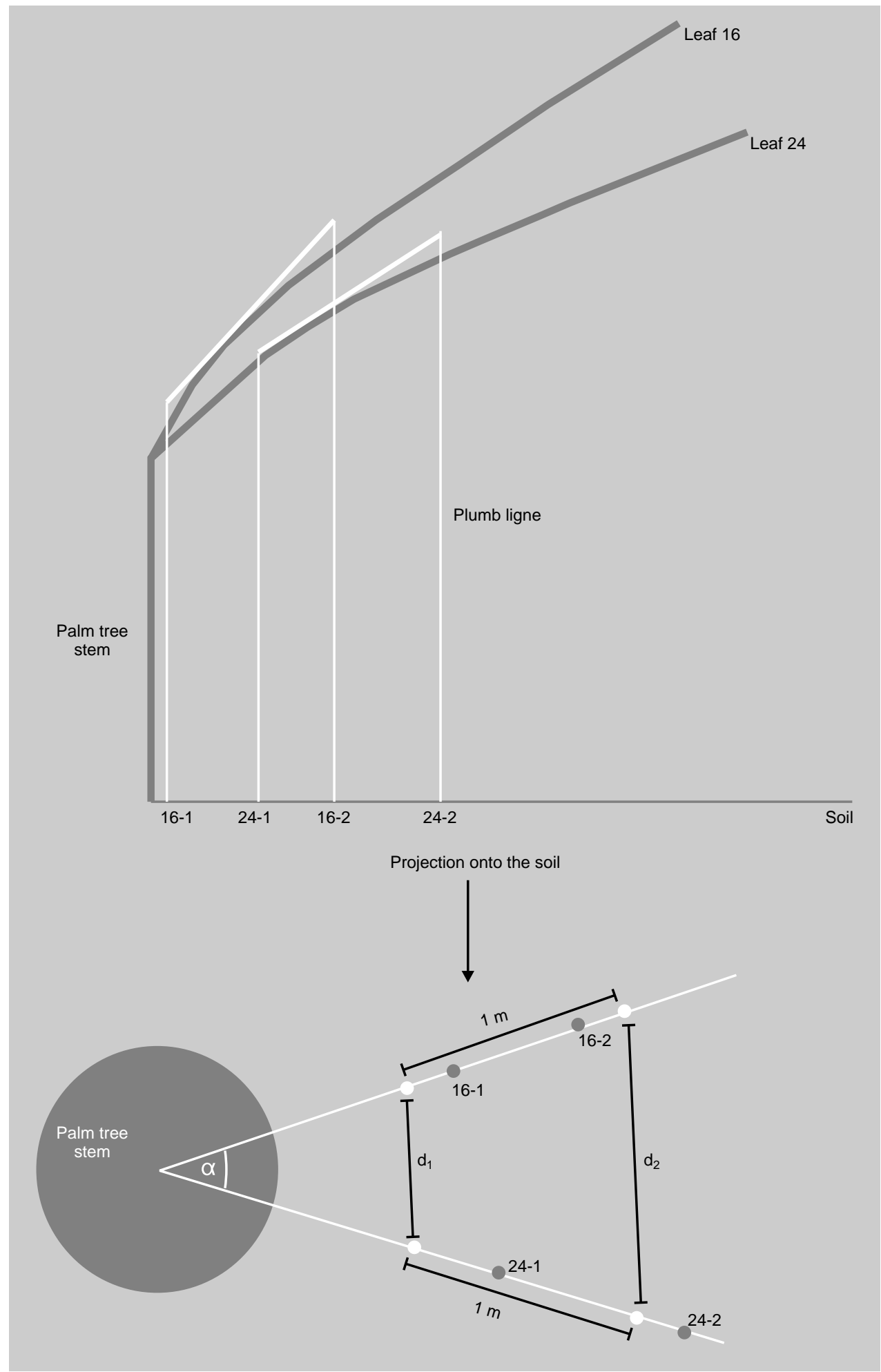

Figure 2.

Measurement of the angle formed by the two leaves 16 and 24 of a palm tree, used to calculate the divergence angle. 


\section{Results}

The frequency data noted for the four cultivars (figure 3) showed that the number of trees showing clockwise and counterclockwise phyllotaxis varied slightly between the different cultivars within each cultivar, while the same frequency is of $50 \%$ for all offshoots and mother trees (figure 4). The most obvious contact parastichies on date palm tree are, in order, spiral 13 , spiral 8 and spiral 5. Graphics show that the frequency of phyllotaxic direction of mother trees is different from that of offshoots (figure 3). There is no correlation between phyllotaxic direction in mother trees and offshoots. Therefore, offshoots present a clockwise or counterclockwise phyllotaxy independently of the mother plant.

The divergence angle in the four cultivars was different, but the mean value remained within a range of $136^{\circ}$ to $137.9^{\circ}$ (figure 5). The cultivars Bousthammie blanche (bsb) and Jihel (jhl) showed the same mean value of $136.2^{\circ}$ for the divergence angle, whereas the cultivars Sair layalet and Bousthammie noire showed angles of $137.0^{\circ}$ and $137.9^{\circ}$, respectively. The value of the divergence angle is not related to phyllotaxic direction.

\section{Discussion}

Our results showed that the frequencies of phyllotaxic direction of all observed trees (offshoots and mother trees) were more or less equal. Studies conducted on phyllotaxis of oil palm and coconut trees showed that the frequency of counterclockwise phyllotaxis was higher than clockwise phyllotaxis in the trees examined [7, 8].

Davis [14] reported that coconut trees with counterclockwise phyllotaxis are predominant in the northern hemisphere whereas clockwise phyllotaxis predominates in the southern hemisphere. Consequently, this would imply that latitude influences phyllotaxis. Davis and Davis [10] mentioned that phyllotaxis in coconut tree is influenced by magnetic latitude. Minorsky

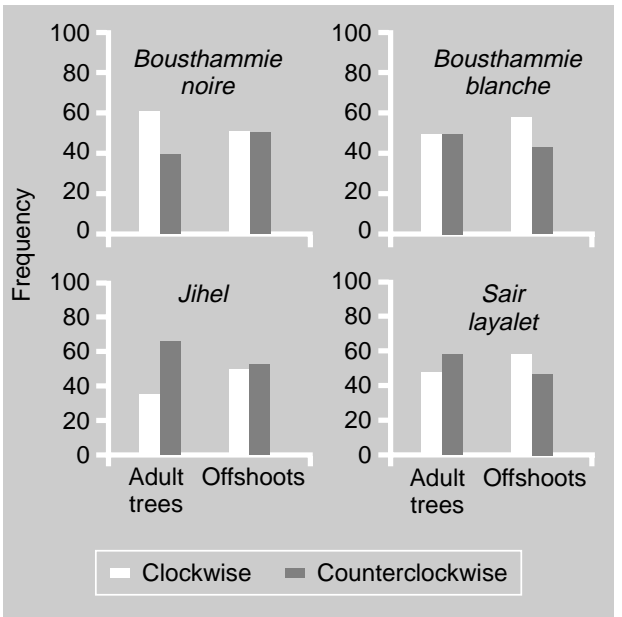

Figure 3.

Phyllotaxic direction frequency according to four date palm tree cultivars (adult trees and offshoots) studied in Morrocco.

[15] explained that coconut trees with counterclockwise phyllotaxis predominate in the northern hemisphere because the auxin brought to the terminal bud tends to circulate in a counterclockwise direction, whereas in the southern hemisphere it turns in the opposite direction.

Offshoots insure propagation of plants identical to the mother trees and provide date production, although Reuveni [11] affirms that trees with counterclockwise phyllotaxis produce more than those with clockwise phyllotaxis.

The cultivars Bousthammie noire and Sair layalet are renowned for their high date production [16]; they have a phyllotaxic angle higher than those of the Jihel and Bousthammie blanche cultivars. Other studies have demonstrated a relationship between phyllotaxis and yield in palm trees $[7,11]$ as well as in other plants [17-19].

The arrangement of the leaves, one with another, is an essential factor in optimizing the photon capture required for photosynthesis. Covering and shading of lower leaves, by upper leaves in particular, should be avoided. Such an arrangement does not allow any leaf to be located exactly on top of another leaf, which reduces the shade effect on lower leaves [20].

The Sair layalet and Bousthammie blanche cultivars have superposed leaves on eight vertical spirals while the Bousthammie noire and Jihel cultivars have horizontally spaced

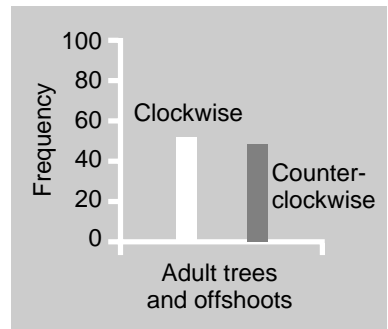

Figure 4.

Phyllotaxic direction frequency of adult date palm

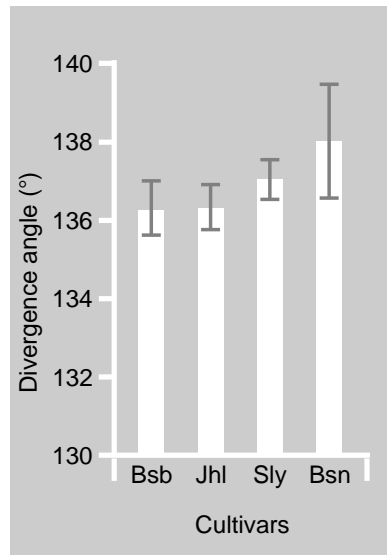

Figure 5.

Variation of divergence angle in four cultivars of Phoenix dactylifera L.

(Bsb: Bousthammie blanche, Jhl, Jihel; Sly: Sair layalet; Bsn: Bousthammie noire). trees and their offshoots. 
leaves on diagonal spirals. Oblique or vertical arrangement of the ' 8 ' parastichies could be explained by a high growth speed of the stem. Indeed, the higher the latter is, the more vertical spirals appeared between two successively emitted leaves. The trees with narrower angles superimpose the leaves on the spiral sequence 8 . This hinders the circulation of air between the leaves and therefore affects gas exchange between the leaf and the atmosphere. A wide phyllotaxic angle predisposes to high light energy absorption and its use for photosynthesis, whereas a narrow angle tends to fold the date palm leaf upon itself and restrict its exchanges with the environment [18].

When water supply is sufficient, incidence of trees with an optimal divergence angle is high. However, under unfavorable conditions caused by severe water shortage, date palm trees with a low angle are favored. In this way, they can limit their energy capture and water loss. Supplementary studies on radiation balance would establish an eventual correlation between yield and phyllotaxic angle.

Phyllotaxic angle appears to be an important factor in determining the capacity of the energetic assimilation of date palm trees. This character is of interest in yield gain and its optimization, in particular, for marginal date palm growing regions.

\section{Acknowledgements}

The authors are thankful to the Director of Inra-Morocco for facilities. Thanks must be given to all the staff of the Inra-Zagora Nbech experimental station. This work was supported by Unesco/Icsu/Twas, Aupelf and Cirad.

\section{References}

[1] Clouet Y., Dolle V., Aridité, oasis et petite production, exigences hydrauliques et fragilité sociale : une approche par analyse spatiale et socio-économique, Sécheresse 9 (2) (1998) 83-94.
[2] Davis T.A., Right-handed, left-handed and neutral palms, Principes 15 (1971) 63-68.

[3] Douady S., Couder Y., La physique des spirales végétales, La Recherche 250 (1993) 24-35.

[4] Jean R.V., Phyllotaxis: a systematic study in plant morphogenesis, Cambridge Univ. Press, Cambridge, UK, 1994.

[5] Adler I., Barabé D., Jean R.V., A history of the study of pyllotaxis, Ann. Bot. London 80 (1997) 231-244.

[6] Davis T.A., The non-inheritance of asymmetry in Cocos nucifera L., J. Genet. 58 (1962) $42-50$.

[7] Davis T.A., The dependence of yield on asymmetry in coconut palms, J. Genet. 58 (1963) 186-215.

[8] Arasu N.T., Foliar spiral and yield in oil palms (Elaeis guineensis Jacq.), Malays. Agric. J. 47 (1970) 409-413.

[9] Louis I.H., Chidambaram A., inheritance studies on the phyllotaxis of coconut palm, CeyIon Coconut Q. 27 (1976) 22-24.

[10] Davis T.A., Davis B., Association of coconut foliar spirality with latitude, Math. Model. 8 (1987) 730-733.

[11] Reuveni 0., Effect of left- and right-handed phyllotaxis on yield of the date palm, Acta Hortic. 175 (1986) 257-258.

[12] Hirsch P.J., Angle de divergence des feuilles du palmier à huile : mesure et conséquences possibles, Oléagineux 33 (1978) 109-112.

[13] De Reffye P., Lecoustre R., Dauzat J., Ouattara S., Flori A., N'Cho Y.P., Modélisation de l'architecture des plantes. Application aux plantes agronomiques pérennes tropicales. Cas particulier des Palmacées, Oléagineux 44 (1989) 537-546.

[14] Davis T.A., Enantiomorphic structures in plants, in: Proceedings of the Indian National Academy of Sciences, indian National Academy of Sciences, india, 1974, pp. 424-429.

[15] Minorsky P.Y., Latitudinal differences in coconut foliar spiral direction: a re-evaluation and hypothesis, Ann. Bot. London 82 (1998) 133-140.

[16] Pereau-Leroy P., Le palmier dattier au Maroc, Service de la recherche agronomique, ministère de l'Agriculture au Maroc, IFAC, Paris, France, 1958

[17] Nikulin A.V., Leisle V.F., Response of plants from left-hand and right-hand sugar beet fruits to terrestrial magnetic field orientation and forms of nitrogen fixation, Sov. Plant Physiol. 17 (1970) 384-389. 
[18] Bible B., Non-equivalence of left-handed and right-handed phyllotaxis in tomato and pepper, HortScience 11 (1976) 601-602.

[19] Rama Swamy N., Bahadur B., Narsaiah G., Seedling handedness in Triticale and its parents. II. Yield in relation to handedness, Curr. Sci. India 53 (1984) 538-539.

[20] Bell A.D., Les plantes à fleurs. Guide morphologique illustré, Masson, Paris, France, 1993.

\section{Sentido dominante de la filotaxis en la palmera datilera (Phœnix dactylifera L.).}

Resumen - Introducción. Este estudio tenía como objetivo medir en campo el ángulo de divergencia de la inserción de las palmas en el tronco de palmeras datileras, determinar la frecuencia de filotaxis derechas o izquierdas de plantas adultas y sus hijuelos, evaluar la relación entre la filotaxis del árbol madre y la de sus hijuelos, y, finalmente, determinar el efecto del ángulo de divergencia de las hojas de palma en la producción de la palmera. Material y métodos. El material vegetal estaba compuesto por cuatro cultivares marroquíes de Phoenix dactylifera L. Las observaciones se efectuaron en el sur de Marruecos en 20 palmeras adultas por cultivar y cuatro hijuelos por palmera adulta. Se midió el ángulo de divergencia en las palmeras adultas mientras que la filotaxis (izquierda o derecha) se observó en palmeras adultas e hijuelos. Resultados y discusión. Nuestro estudio mostró que la filotaxis de los hijuelos es independiente de la de la planta madre. El ángulo de divergencia cambió en función del cultivar. Este carácter es un criterio interesante para elegir cultivares adaptados a una producción marginal de la palmera datilera o a condiciones de producción óptimas.

Marruecos / Pboenix dactylifera / filotaxia

To access this journal online: www.edpsciences.org 